\title{
Do non-governmental organisations bring change or maintain the status quo in times of crisis? A case study of the Marikana massacre in South Africa.
}

\author{
LANGA, M., REBELLO, S., HARMS-SMITH, L.
} Development Journal following peer review. The version of record LANGA, M., REBELLO, S. and HARMSSMITH, L. 2021. Do non-governmental organizations bring change or maintain the status quo in times of crisis? A case study of the Marikana massacre in South Africa. Community development journal [online], 56(2), pages 300-317, is available online at: https://doi.org/10.1093/cdi/bsz023. 
Do Non-Governmental Organisations bring change or maintain the status quo in times of crisis? A case study of the Marikana massacre in South Africa

Prof Malose Langa Orcid.org/0000-0002-3196-3147

Associate professor in the School of Community and Human Development in the Psychology Department at the University of the Witwatersrand and Associate Senior Researcher at the Centre for Study of Violence and Reconciliation. His research interests are trauma of collective violence and the psychology of men (masculinity) in postapartheid South Africa.

\section{Steven Rebello}

Senior Researcher, Centre for the Study of Violence and Reconciliation (CSVR), Johannesburg, South Africa. His research interests include psychodynamic theory, the creation of holding spaces, and the use of critical theory in community-led social interventions.

Dr Linda Harms Smith Orcid.org/0000-0003-4686-0906

Corresponding author: l.h.smith@rgu.ac.uk

Lecturer and Research Degrees Coordinator in the School of Applied Social Studies in the Social Work Department at Robert Gordon University, Scotland (previously at the University of the Witwatersrand, South Africa) and a Research Associate of the University of Johannesburg. Her research interests include critical social work, ideologies of knowledge and practice, Decoloniality, collective trauma, and community work 


\begin{abstract}
This paper reflects on the Marikana massacre of August 2012, subsequent violent strikes and responses by non-governmental organisations (NGOs) as a case study, and provides an analysis about whether these interventions bring transformative change or maintain the status quo in times of crisis. Events associated with Marikana are seen to be embedded in social structures of the time and part of deeper frictions and fractures of social transformation (Alexander, 2013). The role that NGOs might play in this context, must be interrogated as to their facilitation or hinderance of such social transformation. Interviews were conducted with representatives of NGOs intervening in Marikana that provided services of humanitarian assistance, and legal and psychosocial interventions and with mine workers and residents of Marikana about their experiences and views of these services. Findings from the study are illustrative of how NGOs were not primarily motivated to bring about lasting, transformative change but rather attempted to address immediate or short-term needs which, while important, did not account for underlying causes of the crises that they set out to address. Both ideological underpinnings of NGOs and structural conditions produced by state and capital, impact on outcomes of interventions. Given these limitations, it is argued that there is a need for deep critical interrogation through praxis, for NGOs to intervene differently in times of crisis to bring 'real' change and transformation in the lives of those who are marginalized.
\end{abstract}

Key words: Marikana, non-governmental organisations, transformation, change 


\section{Do Non-Governmental Organisations bring change or maintain the status quo in times of crisis? A case study of the Marikana massacre in South Africa}

\section{Introduction}

The circumstances surrounding the Marikana Massacre of August 2012 and subsequent platinum belt labour action, are seen to be embedded in social structures of the time and part of "deeper frictions and fractures of social transformation" (Alexander, 2013). The role that $\mathrm{NGOs}^{1}$ might play in this context, must be interrogated as to their facilitation or hinderance of such social transformation. The Marikana events led to mobilisation of support and services from civil society, non-governmental organisations (NGOs), faith-based organisations, social movements and political organisations (Eyewitness News, 2014; ${ }^{2}$ Gift of the Givers Foundation, 2014; NGO Pulse, 2014). These services ranged from providing food, clothing and infant supplies to spiritual support, counselling and legal aid assistance. Interventions included both such material support, and engaging with the community around the horrific nature of events and poor conditions in which mining families continued to live.

This article stems from debates around general NGO objectives and claims about commitment to social change and transformation, while failing to achieve this (MuellerHirth, 2012; Habib and Taylor, 1999). The arguments made are supported by illustrative findings about the impact of support, services and interventions provided by NGOs to the people of Marikana. The case study explored perceptions around interventions after the massacre of August 2012, following protests led by the Association of Mineworkers and Construction Union (AMCU) and state and mining corporation responses. It focusses on how interventions contribute to social change by being transformative, or hinder social change and simply maintain the status quo.

Various critiques of the value of NGOs generally and during times of crises specifically, in relation to social change and transformation, are relevant. Did those who supported the people of Marikana unwittingly perpetuate the status quo? Do responses to immediate needs represent attempts to curb discontent with growing inequality or genuine efforts at support and solidarity? To what extent are these motivated by a desire to bring about real, sustainable or transformative change? To what extent do specific ideological positions drive decisions and interventions? These questions are explored by reflecting on the manifest objectives, claims and roles of NGOs in contexts of extreme precarity, socio-economic hardship and crisis. Reflecting on conversations with representatives of NGOs involved during and after the period of the Marikana massacre of 2012, and with members of the community that received these services, findings are illustrative of conclusions drawn about status quo maintenance and hindrance of socio-economic

\footnotetext{
${ }^{1}$ Herein, NGOs are viewed as any grouping of people, who operate outside the interests of labour, business or the state, who have a vision of meeting the needs of their community or any grouping of people.

${ }^{2}$ See 'Churches Call for Relief in Marikana', http://ewn.co.za/2014/05/24/Platinum-strike-Churches-call-for-relief-inMarikana (accessed December 2016).
} 
transformation associated with power, politics and privilege, ideologies, the neo-liberal economic context and betrayals by corporations and the state

\section{South Africa - transition from struggle to further struggle}

South Africa's transition from apartheid to democracy has been hailed by many as a miracle (Athiemoolam, 2003; Hamber, 1998). The liberation struggle against white nationalist, racist capitalism in the form of Apartheid, was fought over many decades through civil disobedience and political and armed resistance by political organisations, social movements, civil society and non-governmental organisations (Habib and Taylor, 1999). Promises of a better life for all were made during this process of transition; some of which included that people would have access to basic services such as water, electricity, housing, education, nutritional support and health. The pro-poor Reconstruction and Development Programme (RDP) policy was adopted post 1994 elections - aiming to improve living conditions of all who suffered under apartheid. However, the new South African government were forced, through obligations to the IMF (International Monetary Fund) and the World Bank, to adopt neo-liberal policies such as GEAR (Growth, Economic and Redistribution), which supported privatisation of public services and open market policies (Terreblanche, 2012).

These neo-liberal policies have caused increasing levels of unemployment and inequality (Duncan, 2013; Satgar, 2012; Seekings \& Nattrass, 2011). For instance, South Africa's Gini coefficient increased from 0.61 in 1996 to 0.63 in 2015 (World Bank, 2019). South Africa has witnessed a trend of increasing unemployment, the official rate rising from $22 \%$ in 1994 to 32\% in 2018 (Statistics South Africa, 2018). An expanded definition of unemployment, which includes individuals no longer actively seeking employment, suggests the unemployment rate is closer to 36\% (Statistics South Africa, 2018). When considering levels of poverty and inequality in South Africa, it is evident that the postapartheid government's ongoing pursuance of neoliberal macroeconomic policies is due to an overarching commitment to the aims and dictates of extractive capitalism, which has led to increased inequality.

\section{Marikana Massacre and community response}

Perhaps the starkest example of the legacy of these oppressive, extractive practices occurred in 2012. Whilst the year marked one of close to record prices for platinum, Impala platinum miners' wage protests, in February 2012, were met with up to 18000 dismissals when protests were ruled illegal (Nicolson, 2012). On the $9^{\text {th }}$ of August, a number of miners at Marikana Lonmin mines, similarly downed tools, with some rock drill operators requesting R12,500 - perhaps a 20\% wage increase (Hlongwane, 2012). The next day, violence erupted, with two miners reportedly shot dead. Whilst subsequent investigations found that the shots had been fired by a trade-union official, neo-liberal news-agencies portrayed the miners as violent (Duncan, 2013). After a week of threats of dismissals, failed negotiations and a portrayal of the protest as spiralling out of control, 
South African Police special forces officers moved in to action; shooting and killing 34 miners.

The Marikana massacre, as an historical event, may be seen as a turning point in South African history (Alexander, 2013). Historical events such as these change structures and also "create special vantage points, that have the potential to reveal the deeper frictions and fractures that produce and shape social transformation" (Burawoy, 2001, cited by Alexander, 2013, p. 607). Alexander (2013, p. 607) cites Ruth First describing another such event, the 1946 African miners' strike, as "one of those great historic incidents that, in a flash of illumination, educates a nation, reveals what has been hidden, destroys lies and illusions." Marikana and subsequent developments and conditions, hold similar power to illuminate and educate. According to Alexander (2013, p. 607), such historic turning points "involve sequences of activity released by ruptures; they provide scope for interpretation of actions and structures; and they lead to re-configured structures." These societal responses and 'sequences of activity' as intervention action and activities, provide such scope for interpretation, the purpose of this paper.

Conditions in Marikana and the so-called platinum belt class struggle were not confined to issues in the workplace (Naicker, 2016). Since 2005, there had been increasing numbers of community protests, most of them over provision of basic services (Alexander 2010). In Marikana, besides hazardous and arduous working conditions, miners and their families are subjected to high levels of illness, highly polluted air, abysmal living conditions in shack settlements and lack of services (Alexander, 2013). The lack of services and basic infrastructure by local authorities means that even in postapartheid South Africa, such communities continue to experience subjection to the consequences of the primacy of capital (Benya, 2015). The massacre and ongoing mineworkers' struggles for a living wage may be seen as part of these broader struggles of workers and communities for better life for all.

\section{Contested value of $\mathrm{NGO}^{3}$ involvement}

The roles that NGOs, as a part of what constitutes broader civil society, are able to perform in the achievement of social justice and societal transformation, is a contested issue. There is a "dominant normative assumption on the political role of NGOs" (Mercer, 2002 , p. 6), that they play an important part in democratic development, often understood as serving a liberal-democratic ideology ensuring civic participation and democracy (Seligman, 1992). They are said to create alliances to pressurize the state; represent marginalised groups; and influence public policy. However, "civil society is

\footnotetext{
${ }^{3}$ In this paper, NGOs as a part of 'civil society' but not including social movements or trade unions, mean those non-governmental, not-for-profit organisations set up and run by volunteers at management level, staffed by employed and/or voluntary workers, and funded through donations and at times subsidized by the state. In the South Africa they would operate within the framework of a registered legal entity (in terms of the Non-Profit Act of 1995).
} 
thought to play different roles at different stages of the democratization process" (Mercer, 2002, p. 7).

In South Africa during Apartheid, NGOs encompassed a broad spectrum of political ideologies and frequently sought radical transformation to mobilise, resist and challenge the status quo for socio-political change (Habib and Taylor, 1999). However, most NGO services mirrored racist Apartheid institutional arrangements (Habib, 2005). Those who met black South Africans' basic needs were either permitted but unsupported by the state, whereas those challenging racist oppression, were violently repressed. Many NGOs responding to social justice and survival needs, arose from and participated politically within the anti-apartheid struggle (Habib, 2005; Chipkin, 2012), and so contributed to the conception of the NGO sector as holding promise for radical transformation.

Historically, South African colonial era NGOs had been predominantly European church organisations, with their 'civilising mission', helping people meet physical and spiritual needs, baptising them into Christianity, eroding social and psychological resources and advancing the Colonial project (Bulhan, 2015; Patel, 2005). There was little reflection on why, after thousands of years of successful existence, this was required, or how land dispossession affected these outcomes. Christian missionaries "were as much part of the colonizing forces as were the explorers, traders and soldiers... missionaries were agents of colonialism in the practical sense, whether or not they saw themselves in that light" (Rodney, 1972, p. 277).

This charitable or missionary role of NGOs may also subdue socio-political unrest and discontent - what was designed to serve the poor also maintains social order, protecting the interests of ruling classes and the rich (Manji \& O'Coill, 2002; Kapoor, 2012). These interventions may be described as domesticating and maintaining of the status quo rather than transformative and liberating, producing social change (Harms Smith, 2017). NGOs pursuing socio-economic development agendas for example, thrived in the African context during the time of structural adjustment programmes imposed by Bretton Woods Institutions, ${ }^{4}$ with African countries experiencing deepening levels of debt, unemployment and dependence (Manji \& O'Coill, 2002; Shivju, 2007). For instance, the number of NGOs operating in Kenya, "increased almost threefold during the period 1978 to 1988" (Manji \& O'Coill, 2002, p. 579). Similarly, "between 1984 and 1994, the British government increased its funding to NGOs by $400 \%$ " (Amutabi, 2006, p. 74). Such NGO activity is described as "a mask for maintaining the dominance of free market capitalism" (Banks et al, 2015, p. 707).

Civil society organisations may thus be conceived as "replicating the order imposed by the state throughout society", rather than as independent actor (Fioramonti and Fiori, 2010, p. 85). They may also act, in a Gramscian sense, within "the wider social, economic and political cleavages" (Mercer, 2002, p. 8) of society, serving as "acquiescent support of

\footnotetext{
${ }^{4}$ The World Bank and the International Monetary Fund.
} 
capitalist power" which nonetheless is able to bring about political change by

elaborating and propagating a new conception of the world (Fioramonti and Fiori, 2010, p. 85).

Despite (and sometimes in keeping with) their intentions, NGOs may perpetuate the very conditions that they attempt to alleviate (Tandon, 1996) through services that fill spaces created by state inefficiencies and by failing to reflect critically on their impact as distinct from intentions (Shivju, 2007). Structural oppressions may thus be deepened without emancipatory change. Furthermore, many NGOs are staffed by urban, educated, middle class elites "with no substantive roots in underprivileged groups" (Fowler cited by Mercer, 2002, p. 9).

NGOs also maintain the status quo because of their reliance on funding by private donors and large 'philanthrocapitalists' (Banks et al, 2015), which limits or dictates the scope or type of initiatives they pursue. NGOs not only represent the interests of disadvantaged groups, but also of their own or donor interests (Mercer, 2002; Heise, 2016; Mueller-Hirth, 2010; Tandon, 1996), often accountable to multiple stakeholders with varying expectations (Heise, 2016). As a result of these problematic relationships, their role has been described as 'well-mannered activism' (Mueller-Hirth, 2010, p. 239), as many funders discourage and are even hostile to social-change efforts or exposure of social issues such as poverty and inequality (Shivju, 2007).

In South Africa, the neo-liberal agenda (Kotze, 2003, p. 17) after 1994 meant that many organisations "lost their critical role and became caught up in demands of donor- and government-driven 'development' agendas." State/NGO relationships became more antagonistic (Habib, 2005), highlighted by cases such as the Treatment Action Campaign's lengthy advocacy and (successful) legal matter against the state's refusal to provide anti-retroviral medication to prevent HIV transmission from mother to child (Grebe, 2011).

Although protests, social movements and trade unions in the context of socio-political and economic crises such as Marikana, have been studied (Alexander, 2013), assessment of the role of NGOs in relation to these crises, has received less attention. Many NGOs' work and responses to crises have focused on symptoms rather than underlying causes of issues they attempt to alleviate (Kotze, 2003; Manji \& O'Coill, 2002). Ideologically, such interventions generally represent a liberal position, development discourse of the state, and invoke human rights in the ideal rather than in the material (Harms Smith, 2017). Lacking critical reflection, NGOs are often palliatives to effects of deteriorating structural socio-economic conditions (Fowler, 1995). Manji and O'Coill (2002) argue that NGOs in the African context have become the new missionaries, with potential to empower people, but tending to maintain their paternalistic, developmental role. Instead of prioritising justice and rights, many NGOs work from a developmental discourse motivated by charity and pity. 


\section{Exploring the views of community members and $N G O$ representatives}

This case study, based on a qualitative, interpretive research design, explored meanings attributed to NGO involvement in the Marikana context, to develop deeper understandings of emergent issues (Cresswell, 2007; Denzin \& Lincoln, 2005). This constructivist approach meant that meanings attributed to events could be better understood through reflective and interactive dialogue (Ponterotto, 2005) about experiences and perceptions on the assistance provided in Marikana.

Two groups of participants, namely community members and representatives from NGOs, were approached and selected using non-probability, purposeful criterion sampling (Patton, 1990). The criteria were that community participants had to have lived in Marikana since early 2012 and that the NGOs had to have provided services in Marikana after the massacre of August 2012. Additional snowball sampling (Bryman, 2012) was used so that initial participants could refer further participants.

Fifteen community members were included, who were members of local communitybased organisations, or active citizens referred by these organisations, and individuals randomly approached through a street corner approach (Brown and Durrheim, 2009). Initial unstructured interviews with community members were held in November 2012, three months after the massacre, with more interviews in 2015 and early 2016.

Participants included men and women of various ages and affiliations -trade unions, political organisations, community-based organisations and a traditional council from the area. These interviews explored perceptions about interventions and the resultant changes in Marikana.

Nine representatives of NGOs that had responded to the crisis were recruited through the researchers' networks, and through news media reports identifying organisations that had provided support and services to people of Marikana between 2012 and 2014. These NGOs had provided humanitarian, psychosocial and counselling support, and had made efforts to mobilise community members and raise awareness through collecting miners' narratives. More formal interviews, guided by structured interviews schedules, were conducted with these participants.

Ethical considerations such as confidentiality and anonymity, voluntary participation and informed consent, were taken into account and consent forms signed before conducting interviews. Thematic analysis was used to identify, analyse and report identified themes (Braun \& Clarke, 2006). An inductive approach was used with coding largely driven by data as opposed to existing frameworks (Braun \& Clarke, 2006). Themes identified included the short-term nature of interventions; the role of politics and the state; the racialised and liberal nature of charity work; and beneficent intervening. These findings were illustrative of some of the concerns around the contested nature of NGO involvement in social change and transformation. 


\section{Focusing on short-term needs vs. long-term change}

Interventions by NGOs were perceived to have brought little to no change. In fact, some participants felt that they now faced even greater challenges. It was evident that many NGOs were not primarily motivated to bring about lasting or transformative change, in spite of organisational objectives relating to wellbeing and societal change. Interventions generally attempted to address immediate, short-term needs which, while important, elided the underlying causes of these crises of socio-economic deprivation and collective traumatisation. Interventions which aimed to empower and mobilise community members perhaps failed to consider how the organisation's later absence may have made it difficult for community members to access social capital and resources needed for long-lasting change.

Many NGO participants understood the massacre and the violent strike to be a tragedy that required humanitarian or charitable support. As a result, these interventions may have set out to alleviate immediate suffering, feeding those who were desperately hungry.

I think ultimately our goal was just to bring relief to this cry of hunger, and to bring people just a little bit of comfort, little bit of hope, little bit of - oh, you know what, we are not forgotten! Ya, just that is hope that we brought to people. I think that was the most important thing.

Our main worry was people starving and sleeping without food because of the strike. We did not want to sleep without eating.

Some NGO participants were explicit about the intentional short-term nature of their involvement and the lack of long-term impact. This was especially so for an organisation focussing primarily on disaster relief management.

So people were really, really struggling. And basically [we] went in there not as much as to... we didn't make like a long-term difference. The difference that we went to go and make was short term. But yes, we had the buy-in of the South African people. South African people were very supportive.

Other NGO representatives were more defensive when questioned about potential longterm impact of interventions, possibly feeling delegitimised. However, while there may have been some defensiveness around the potential lack of long-term impact, it is possible that their focus was only on short-term outcomes, never considering possible contribution to long term or structural change, or that they were unable to evaluate long-term impact.

It's worthwhile evaluating the impact of it now, if you can do that. But personally, it is very difficult to evaluate the impact. What I know is that - because I meet with people from Marikana occasionally, there is a call actually for people to come and help in some 
instances, because there are still people killing themselves. I mean this is just a fact... although different organisations did try to provide psychological support.

I don't think this is an aspect that we ever thought about the long-term effect of our work. We were just there to help people who were in need. We did not think about all those things and bringing change. I don't want to lie.

\section{Power, politics and the role of the state}

Whilst interview schedules did not include a focus on the state or politics, it was interesting that community members often related the Marikana massacre to inefficiency of ANC-led government and its failure to resolve the impasse between the union and Lonmin. Subsequent NGO interventions were perceived to occur in the context of a culpable and absent state

The ANC did nothing to help AMCU and get everyone to the table and talk about the strike.

We feel the government has failed to control things before they got out of control. Even after the government did not show any concern about the situation in Marikana. Till to date nothing has changed.

We did not expect an event like this in the new South Africa. ANC is our liberation movement. It was hurting to see how the ANC has responded to this event. It was shocking and hurtful. The ANC basically did nothing to assist the people of Marikana.

Participants from both NGOs and the community argued that the protest could not be separated from politics of the ANC-led government. AMCU was seen as an opposing union in conflict with NUM, more aligned to the ruling party (ANC) (Sinwell, 2015). Politics of inter-union rivalry appear to have made it difficult for the ruling government to intervene prior and post the massacre. Both groups of participants were aware of these politics of power and privilege and felt that the ANC had drifted from its liberatory narrative of being the party of and for the people. The ANC's lack of response directly after the massacre was experienced as abandonment and complicity with capital in the form of Lonmin, in which the current president of the ANC and South Africa, Cyril Ramaphosa had shares.

One NGO participant had been involved prior to the massacre in attempts to hold Lonmin accountable for its social responsibility duty, as enshrined in the Mining Charter (Diale, 2014), to develop the community of Marikana and provide access to basic services such as housing and sanitation. He expressed his sense of sadness and despondency that nothing had changed, prior to or post the killing of the 34 mineworkers.

I was aware of what is actually happening and over years I have been interacting with Lonmin, trying to get Lonmin to work fairly with communities. But they had always told lies, they had always come out with fancy reports and all that. So there was no way really 
I could just stand by and watch as workers were trying to get what is actually due to them. But at the end of the day, I think the people with resources just don't care. I think it's a fundamental selfishness.

This participant asserted that the massacre was a sign of a deep-seated problem about lack of accountability by mines such as Lonmim, to comply with the Mining Charter.

For many participants, the story of Marikana exposed the extreme socio-economic inequalities in South Africa. NGO interventions failed to engage with this, or how class relations in South Africa could be transformed, nor did they challenge the current socioeconomic status quo of ongoing exploitation by capitalist mining companies such as Lonmin.

\section{Racialised and liberal politics of NGO 'charity' work}

Politics of race and privilege are ubiquitous in South African NGO, development and charity work (Bozalek and Biersteker, 2010; Kessie, 2013). Kotari (2006) argues that silence around race, its hierarchies and the power of whiteness in development ideologies, institutions and practices, obfuscates its effects on processes and consequences of development. Reflexivity around such racialised positioning, would "assist in the realignment of forms of engagement in development in a racially cognisant manner that resists inequalities of power" (Kotari, 2006, p. 15).

It is noteworthy that many NGOs that intervened in Marikana were led by white activists, and priests. Such acts of charity may represent white South Africans' attempts to distance themselves from their racism and privilege by giving something back to those negatively affected by their privilege (Hook, 2011). The surfacing of the issue of gratitude in the benefactor/beneficiary relationship allows for a discussion of power embedded in the concept of charity (Livingstone, 2013). Those who have greater access to resources hold power over those who do not, particularly in contexts of great scarcity (Kapoor, 2012; Livingstone, 2013). This power dynamic contributes to a transactional relationship, that may require gratitude for resources, or perpetuate the power imbalance of generous benefactor and subservient or docile recipient.

The manner in which some NGO participants evaluated their interventions according to community members' level of gratitude, and whether their efforts were valued, fits with Hook's (2011) concept of charitable anti-racism, where numerous ego gains follow from the other's recognition of the giver's goodness. Drawing on Biko (1978) and Ahmed (2004), Hook (2011) argues that acts of charity may represent white South Africans' attempts to distance themselves from their racism and privilege by giving something back to those who are negatively affected by this privilege, in order to feel redeemed (Hook, 2011).

However, in other instances, representatives from NGOs recognised larger historical and political factors that contributed to the massacre but failed to incorporate these 
considerations into their interventions. Whilst this difficulty may have related to any number of issues, some NGO participants' reflections on their lived experiences and privilege, suggest these experiences may be difficult to negotiate or tolerate.

I picked up on the silence. And to have all these men standing in silence is massively confronting. And for me, as an individual, you get confronted by your own worth, you get confronted by your own // I mean I come from this kind of resourced place. I've never ever had to stand in a queue to be helped. And it's confrontational

After [watching the Miners Shot Down documentary], I had an absolute pain in my heart. I got home, my husband didn't come that night [...] And he said, you will not talk to me, you will come and sit down - and he was watching [a comedy movie]. I said to him I do not want to watch [this movie], because I am very angry at what I have seen. He said you will be quiet and watch [the movie].

Reflexivity around these power dynamics would lead to a position of solidarity and potential for transformative social change. The importance of solidarity in bringing about change is recognised by many community workers and community psychologists (McMillan \& Chavis, 1986; Nelson \& Prilleltensky, 2010). Where NGOs emerge from the South African context of past and ongoing oppressive relationships, Freire's $(2005$, p. 50$)$ view that true solidarity is a radical posture becomes relevant: "The oppressor is in solidary with the oppressed only when he stops regarding the oppressed as an abstract category and sees them as persons who have been unjustly dealt with, deprived of their voice, cheated in the sale of their labour". Such solidarity enables consciousness of the structural relationships at play.

Many NGOs adopted a liberal, paternalistic approach, reinforcing structural relationships of racialised privilege. This failed to create a dialogical approach in which community members, and those who intervened, could simultaneously reflect on and act upon their world through praxis. Those intervening would then have to consider the agency and competence of marginalised and oppressed groups over their reality and the importance of solidarity with their resistance to abuses of power and efforts to bring about social change.

\section{Beneficent intervention practices}

Some organisations that intervened in Marikana were reported to be highly reflective about their involvement, adopting a collaborative approach rather than expert role. This involved talking and listening to community members during needs-assessment, allowing for greater understanding of challenges facing the community, how to support them, as well as demonstrating respect for community members' dignity.

So, we made various visits, we just listened. Often women just wanted to talk about what had happened and what they were experiencing. 
Secondly, working 'with' as opposed to 'for' the community meant upskilling and empowering through awareness raising, training and creating community-led and based organisations. This demonstrated the desire to intervene sustainably, enabling community members to provide services in their communities even after those who intervened had left.

So, we started by... we were even including priests, anyone who was just willing to come on board to support. And we did intensive training I would say, just for them to be able to provide basic emotional support and then refer. This was to empower people of Marikana to use these skills even after we left.

Thirdly, some organisations focused on ethical implications of interventions by examining the benefits that community members would reap. It was important to ensure that the interventions did not perpetuate inequality.

I think at the same time the intention was to - how as an organisation [do we] leave the community standing. The approach was, we shouldn't just go there and extract. More has been extracted already from these people. What is it that we can bring? Not like we're exchanging, but then really leave people with something that they can be able to hold on to. We needed to discuss strategies on how some of the initiatives may be sustained.

However, although some organisations were concerned about making their interventions sustainable, limited resources meant that they were unable to follow-up to ensure this. It was argued that the state also needed to intervene in helping the people of Marikana on a long-term basis.

\section{Concluding remarks}

This study set out to determine the perceived impact of the support and services provided to the people of Marikana between 2012 and 2015. Findings suggest that there is a general sense that nothing had changed in Marikana since the massacre in 2012. While a small number of participants felt that there had been some changes, most feel that life is even more difficult since 2012.

In response to this, the study moved to determine why, despite the best intentions of those who intervened, nothing appears to have changed in Marikana. Findings highlighted that real, lasting or transformative change was not necessarily the primary motivation of those who intervened in Marikana.

On the other hand, it may be argued that hope for such change was going to be a failure from the start - due to both the ideological underpinnings of NGOs and structural conditions produced by the state and capital. In this sense NGOs may be seen as collaborators - for maintaining status quo, injustice and inequality. Any efforts that fall short of substantial social change will of necessity support existing government and 
capital interests. Structural arrangements of government and capital provide a context of impossibility for real change. This would have required large scale social action and mobilisation to strengthen workers' and communities' actions.

Findings also suggest that some of those who intervened did not critically reflect upon factors that precipitated or perpetuated events that unfolded in Marikana. Others were aware of various underlying factors - for example, difficulties in challenging existing politics and power dynamics, as well as a lack of accountability from the government, SAPS and Lonmin - but struggled to challenge them.

The miners' ability to resist abuses of power also brought into question why, when and how NGOs as part of civil society, should work with communities. This does not deny their important role in meeting the needs and protecting the rights of marginalised or disempowered groups, but it suggests that civil society should consider how to assist community members in gaining greater control or mastery over their lives.

This study raised the importance of critically reflecting on motives, ideologies or reasons for intervening in communities. Although NGOs may see themselves as benevolent actors, it is only at best that they participate in and contribute to structural change, but often at worst, they are a hinderance to these efforts. While critiquing the role that NGOs play in bringing about change may have appeared too critical for some, it is perhaps only through praxis, and deep interrogation of intentions of society as a whole, that all South Africans can move towards real or transformative change.

This project was funded through grants from the South African National Research Foundation (NRF) and the Centre for the Study of Violence and Reconciliation (CSVR)

\section{Reference list}

Amutabi, M.N. (2006) The NGO factor in Africa: The case of arrested development in Kenya. Abingdon: Routledge and Taylor.

Alexander, P. (2013) The Review of African Political economy, 40(38), 605-619.

Athiemoolam, L. (2003) South Africa's peaceful transition to democracy: Nine years of peace in a troubled world, Paper presented at the Peace as a Global Language Conference II, Accessed at: http://www.zsn.unioldenburg.de/download/Logan Japan Conference.pdf (8 December 2015).

Banks, N., Hulme, D. and Edwards, M. (2015) NGOs, states, and donors revisited: still too close for comfort? World Development 66, 707-718.

Benya, A. (2015) The invisible hands: women in Marikana, Review of African Political Economy, 42(146), 545-560 http://dx.doi.org/10.1080/03056244.2015.1087394 
Bozalek, V. \& Biersteker, L. (2010) Exploring Power and Privilege Using Participatory Learning and Action Techniques, Social Work Education, 29(5), 551-572. DOI: 10.1080/02615470903193785

Braun, V., \& Clarke, V. (2006) Using thematic analysis in psychology. Qualitative research in psychology, 3 (2), 77-101. DOI: 10.1191/1478088706qp063oa

Brown, L., \& Durrheim, K. (2009) Different Kinds of Knowing: Generating Qualitative Data Through Mobile Interviewing. Qualitative Inquiry, 15(5), 911-930.

https://doi.org/10.1177/1077800409333440

Bryman, A. (2012) Social research methods (4 ${ }^{\text {th }}$ Ed.), New York, Oxford University Press.

Bulhan, H. (2015) Special Thematic Section on "Decolonizing Psychological Science" Stages of Colonialism in Africa: From Occupation of Land to Occupation of Being. Journal of social and political psychology, 3(1), 239-256, DOI:10.5964/jspp.v3i1.143

Chipkin, I. (2012) Theories of change in social justice initiatives: To what extent are social justice initiatives in South Africa guided by coherent theories of how they make an impact and how can such theories be made more likely to succeed? Johannesburg, The Raith Foundation, Accessed at www.raith.org.za/docs/Theories-of-Change-in-socialjustice-initiatives.doc October 11, 2015.

Cresswell, J. W. (2007) Qualitative inquiry and research design: Choosing among five approaches ( $2^{\text {nd }} E d$.), CA, Thousand Oaks, Sage.

Denzin, N. K. and Lincoln, Y. S. (2005) The SAGE handbook of qualitative research, Thousand Oaks, Sage Publications.

Diale, A. (2014). Corporate social responsibility in the South African mining industry: necessity, conformity or convenience? International Journal of Business and Economic Development 2(1),16-26.

Duncan, J. (2013) South African journalism and the Marikana massacre: A case study of an editorial failure, The Political Economy of Communication, 1(2), 65-88.

http://www.polecom.org/index.php/polecom/article/view/22/197

Eye Witness News (2014, May 24) Churches call for relief in Marikana, Eye Witness News, Accessed at: http://ewn.co.za/2014/05/24/Platinum-strike-Churches-call-for-relief-inMarikana (11 December 2015)

Fanon, F. (1963) The wretched of the Earth, New York, Grove Press.

Fowler, A., Goold, L. and James, R. (1995) Participatory self-assessment of NGO capacity Occasional Papers Series No: 10, International NGO Training and Research Centre (NTRAC)

https://www.humanitarianlibrary.org/sites/default/files/2014/02/intrac 1995_participator y self assessment on ngo capacity.pdf 
Freire, P. (2005) Pedagogy of the oppressed (30 ${ }^{\text {th }}$ Anniversary Ed.), New York, Continuum (Original work published 1970).

Gift of the Givers (2014) Distribution on Platinum Belt continues. Gift of the Givers. Accessed at: http://www.giftofthegivers.org/disaster-relief/south-africa/927-2014disaster-relief-sa/north-west-platinum-miners/4017-distribution-on-platinum-beltcontinues (15 December 2015)

Grebe, E. (2011) The Treatment Action Campaign's Struggle for AIDS Treatment in South Africa: Coalition-building Through Networks. Journal of Southern African Studies. 37(4), 849-868. DOI: 10.1080/03057070.2011.608271

Habib, A and Taylor, R. (1999) South Africa: Anti-Apartheid NGOs in Transition. International Journal of Voluntary and Non-profit Organizations 10(1), 73-82

Habib, A. (2005) State-civil society relations in post-apartheid South Africa. In: John Daniel, Adam Habib, Roger Southall (2005). State of the nation South Africa 2003-2004, Cape Town: Human Sciences Research Council Press pp. 227-241

Hamber, B. (1998). Who pays for peace? Implications of the negotiated settlement for reconciliation, transformation and violence in a post-apartheid South Africa. Paper presented at the Annual General Meeting of the Catholic Institute for International Relations, Accessed at: http://www.csvr.org.za/index.php/publications/1709-who-paysfor-peace-implications-of-the-negotiated-settlement-for-reconciliation-transformationand-violence-in-a-post-apartheid-south-africa.html (15 December 2017)

Harms Smith, L. (2017) Blaming the poor: Strengths and development discourses that obfuscate neoliberal and individualist ideologies, International Social Work, 60(2) 336350

Harmse, L. (2013). South Africa's gini coefficient: Causes, consequences and possible responses. Unpublished MA dissertation. University of Pretoria, Pretoria. Accessed at: http://repository.up.ac.za/bitstream/handle/2263/40181/Harmse South 2013.pdf?seque nce $=1$ (10 May 2017)

Heise, A (2016) Why has economics turned out this way? A socio-economic note on the explanation of monism in economics, The Journal of Philosophical Economics:

Reflections on Economic and Social Issues, X(1), 81-101.

Hlongwane, S. (2012) Analysis: The worthless Marikana peace accord, Daily Maverick, Accessed at: https://www.dailymaverick.co.za/article/2012-09-10-analysis-the-worthlessmarikana-peace-accord/ (10 September 2012)

Hook, D. (2011) Retrieving Biko: A black consciousness critique of whiteness. African Identities, 9(1), 19-32. 
Kapoor, I. (2012) Celebrity humanitarianism: The idea of global charity, London, Routledge.

Kessie, S. (2013). Re-politicizing race in community development: using postcolonial psychology and photovoice methods for social change. Psychology in Society 45, 17-35

Kotari, U. (2006). An agenda for thinking about 'race' in development. Progress in Development Studies. 6(1), 9-23. https://doi.org/10.1191/1464993406ps124oa

Kotze, H. (2003) Development Update. Centre for Civil Society, UKZN. Accessed at: http://ccs.ukzn.ac.za/files/Kotze.pdf

Livingstone, N. (2013) Capital's charity, Capital and Class, 37(3),347-353.

Luther King, M. Jnr. (1968) Martin Luther King, The Spectator, Accessed at: http://archive.spectator.co.uk/article/20th-december-1968/26/martin-luther-king (3 September 2016)

Manji, F. and O'Coill, C. (2002) The missionary position: NGOs and development in Africa, International Affairs (Royal Institute of International Affairs 1944-), 78(3), 567-583. https://www.jstor.org/stable/3095891

McMillan, D. W. and Chavis, D. M. (1986) Sense of community: A definition and theory, Journal of Community Psychology, 14(1), 6-23 http://dx.doi.org/10.1002/15206629(198601)14:1<6::AID-JCOP2290140103>3.0.CO;2-I

Mercer, (2002) NGOs, civil society and democratization: a critical review of the literature Progress in Development Studies 2(1), 5-22

Mueller-Hirth, (2010) Freedom Betrayed: NGOs and the Challenges of Neoliberal Development in the Post-Apartheid Era, PhD Thesis Goldsmiths, University of London. Mueller-Hirth, (2012) If you don't count, you don't count: Monitoring and evaluation in South African NGOs, Development and Change 43(3), 649-670. DOI: 10.1111/j.14677660.2012.01776.x

Naicker, C. (2016) Worker Struggles as Community Struggles: The Politics of Protest in Nkaneng, Marikana. Journal of Asian and African Studies, 51(2), 157-170.

https://doi.org/10.1177/0021909615605533

Nash, A. (2015) Marikana's path, Social Dynamics, 41(2), 387-391.

http://hdl.handle.net/11427/25243

Nelson, G. and Prilleltensky, I. (Eds.) (2010) Community Psychology: In pursuit of liberation and well-being ( $2^{\text {nd }} E d$.). New York: Palgrave MacMillan.

NGO Pulse. (2014) Food parcels show wide support for the miners'strike. NGO Pulse. Accessed at: http://www.ngopulse.org/press-release/food-parcels-show-wide-supportminers-strike N(28 November 2015) 
Nicolson, G. (2012) Impala strike: Welcome to the age of retail unionism, Daily Maverick, Accessed at: https://www.dailymaverick.co.za/article/2012-02-22-impala-strike-welcometo-the-age-of-retail-unionism/ (22 November 2012)

Patel, L. (2015) Social welfare and social development. South Africa: Oxford University Press.

Patton, M. (1990) Qualitative evaluation and research methods, California, Sage.

Peyper, L. (2016) Zuma defends SAA chairperson Dud Myeni, News 24, Accessed at http://www.fin24.com/Companies/Industrial/zuma-defends-saa-chairperson-dudumyeni-20160913 (13 November 2016)

Pieterse, E. (1997) South African NGOs and the trials of transition, Development in Practice 7(2), 157-66.

Ponterotto, J. G. (2005) Qualitative research in counselling psychology: A primer on research paradigms and philosophy of science, Journal of counselling psychology, 52(2),126-136. http://dx.doi.org.ezproxy.rgu.ac.uk/10.1037/0022-0167.52.2.126

Quintal, G. (2015) Phiyega the 'largest victim' in Marikana Report - Mpofu, News 24, Accessed at: http://www.news24.com/SouthAfrica/News/Phiyega-the-largest-victim-inMarikana-report-Mpofu-20150625 (21 November 2015)

Satgar, V. (2012) Beyond Marikana: The post-apartheid South African state, Africa Spectrum, 47(2-3), 33-62. http://hup.sub.uni-hamburg.de/giga/afsp/article/view/550

Seekings, J. and Nattrass, N. (2011) State-business relations and pro-poor growth in South Africa, Journal of International Development, 23(3), 338-357.

Shivju, I. G. (2007) Silences in NGO discourse: The role and future of NGOs in Africa, Nairobi: Fahamu - Networks for Social Justice. Accessed at: https://www.oozebap.org/biblio/pdf/2011/shivji forweb.pdf (12 July 2015)

Sinwell, L. (2015) 'AMCU by day, workers' committee by night': Insurgent Trade Unionism at Anglo Platinum (Amplats) mine, 2012-2014, Review of African Political Economy, 42(146), 591-605, DOI: 10.1080/03056244.2015.1086325

Statistics South Africa. (2018) Quarterly labour force survey - Quarter 2: 2018 (Statistical release P0211), Pretoria, Statistics South Africa, Accessed at:

http://www.statssa.gov.za/publications/P0211/P02112ndQuarter2018.pdf (12 August 2018).

Tandon, Y. (1996) Reclaiming Africa's agenda: Good governance and the role of the NGOs in the African Context, Australian Journal of International Affairs, 50(3), 293-303. 
Tangri, R. and Southall, R. (2008) The Politics of Black Economic Empowerment in South Africa, Journal of Southern African Studies, 34(3) 699-716.

https://doi.org/10.1080/03057070802295856

Terreblanche, S. (2012) Lost in transformation: South Africa's search for a new future since 1986, South Africa, KMM Review Publishing.

Wadongo, B. I. (2014) Performance management and evaluation in non-profit organisations: An embedded mixed methods approach. Unpublished doctoral thesis. University of Bedfordshire, Bedfordshire. Accessed at: http://uobrep.openrepository.com/uobrep/handle/10547/333444 (21 April 2005) World Bank (2019). World Bank in South Africa: Overview. Accessed at: https://www.worldbank.org/en/country/southafrica/overview (20 June 2019) 